\title{
EFEKTIVITAS SUPERVISI KEPALA SEKOLAH DALAM PENINGKATAN MUTU LULUSAN (STUDI KASUS DI SEKOLAH MENENGAH KEJURUAN PELITA IV JAKARTA BARAT), 2018
}

\author{
Argalita Moewardi
}

Hotner Tampubolon

hotnertampubolon@yahoo.com

\author{
W.B.P. Simanjuntak
}

\begin{abstract}
Abstrak
Melalui kegiatan supervisi, kepala sekolah dapat memberikan bimbingan, motivasi dan bantuan teknis serta membantu memfasilitasi media pembelajaran bagi guru yang mengalami kesulitan dalam pembelajaran sehingga dapat meningkatkan profesionalisme guru. Tujuan penelitian ini untuk mengetahui efektivitas supervisi yang meliputi program, pelaksanaan, evaluasi, faktor pendukung dan faktor penghambat yang dihadapi kepala SMK Pelita IV Jakarta Barat.

Penelitian ini menggunakan metode deskriptif dan pendekatan kualitatif, teknik pengumpulan data melalui observasi, wawancara, dan dokumentasi, subjek penelitian kepala sekolah, guru dan siswa. Data dianalisis dengan cara mereduksi, display, mengambil kesimpulan dan verifikasi data.

Hasil penelitian menunjukkan : 1) penyusunan program supervisi dilakukan pada setiap awal tahun ajaran melalui kegiatan rapat dengan melibatkan guru. 2) supervisi dilaksanakan berdasarkan jadwal yang telah ditentukan oleh tim pelaksana supervisi. Teknik supervisi yang digunakan adalah teknik individual dan kelompok meliputi kunjungan kelas, percakapan pribadi, diskusi sebagai proses kelompok, tukar menukar pengalaman, diskusi dan seminar. 3) Evaluasi supervisi dilakukan pada setiap akhir semester. Hasil evaluasi akan dipertahankan dan ditingkatkan apabila sudah mencapai tujuan, sedangkan kekurangan akan dianalisis dan mengadakan perbaikan-perbaikan dalam penyusunan program pada tahun berikutnya. 4) faktor pendukung pelaksanaan supervisi adalah guru menanggapi secara positif tentang pelaksanaan supervisi, terjalinnya hubungan yang baik antara guru dengan guru dan kepala sekolah dengan guru dan timbulnya kesadaran guru meningkatkan kemampuannya, dengan menggunakan fasilitas yang tersedia di sekolah tersebut. Sedangkan hambatan-hambatannya adalah adanya guru yang tidak hadir waktu pelaksanaan supervisi yang disebabkan karena sakit, izin, dan mengikuti pelatihan, adanya guru yang gugup ketika dilakukan supervisi dan kesibukan kepala sekolah.

Efektivitas profesionalisme guru dalam meningkatkan mutu lulusan sudah baik hal ini terlihat dari keterserapan lulusan dari SMK Pelita IV Jakarta Barat di perusahaanperusahaan ataupun di universitas.
\end{abstract}

Kata kunci: supervisi, profesionalisme guru, dan mutu lulusan 


\begin{abstract}
Through supervisory activities the principal can provide guidance, motivation and technical assistance to teachers who have difficulty in learning so as to improve the professionalism of teachers. The purpose of this study to determine the effectiveness of supervision which includes the program, implementation, evaluation, supporting factors and constraints faced by the head of SMK Pelita IV West Jakarta. This research uses descriptive and qualitative approaches, data collection techniques through observation, interview, and documentation, principal research subjects, teachers and students. Data were analyzed by reducing, displaying, concluding and verifying data. The results showed: 1) the preparation of the supervision program was conducted at the beginning of each school year through the meeting activities involving teachers. 2) supervision is carried out based on the schedule determined by the supervising team. The supervision techniques used are individual and group techniques including class visits, personal conversation, discussion as group process, exchange of experiences, discussions and seminars. 3) Evaluation of supervision is done at the end of each semester. Evaluation results will be maintained and enhanced when the objectives are achieved, while the shortcomings will be analyzed and make improvements in the preparation of the program in the next year. 4) the supporting factor of supervision implementation is the teacher respond positively about the implementation of supervision, good relationship between teacher with teacher and principal with the teacher and the teacher awareness raising increase its ability. While the barriers are the absence of supervision due to illness, permission, and training, teachers are nervous when supervised and busy principals. The effectiveness of professionalism of teachers in improving the quality of graduates is good this is evident from the absorption of graduates from SMK Pelita IV West Jakarta in companies or universities.
\end{abstract}

Keywords: supervision, teacher professionalism, and graduate quality 


\section{PENDAHULUAN}

Pendidikan memiliki peranan penting dalam upaya meningkatkan kualitas sumber daya manusia yang professional. Lembaga pendidikan yang mampu membantu meningkatkan kualitas sumber daya manusia adalah sekolah. Sekolah sebagai suatu organisasi yang menjalankan proses pendidikan dengan segala fungsi dan hasilnya, mempunyai perangkat untuk mewujudkan fungsi dan tugasnya melalui manajemen pedidikan yang digunakan, sebagai pelaksana manajerial sekaligus leadernya dalam organisasi sekolah adalah kepala sekolah. Kepala sekolah memegang peranan sukses dan tidaknya dalam pelaksanaan proses pendidikan. Keberadaan kepala sekolah sebagai kunci sukses pelaksanaan proses harus mampu memahami fungsi dan tugas serta tanggungjawab yang melekat yaitu; fungsi leader, manajer, edukator, supervisor, administrator, inovator, dan monitor. Keberadaan kepala sekolah dalam menjalankan fungsi, tugas dan tanggungjawabnya tidak terlepas dari peran serta guru, staff administrasi dan siswa.

Dalam pelaksanaan fungsi dan tugasnya, guru sebagai profesi menyandang persyaratan tertentu sebagaimana tertuang di dalam Undang- Undang Republik Indonesia Nomor 20 tahun 2003 tentang Sistem Pendidikan Nasional. Dalam pasal 39 (1) dan (2) dinyatakan bahwa : Tenaga kependidikan bertugas melaksanakan administrasi, pengelolaan, pengembangan, pengawasan, dan pelayanan teknis untuk menunjang proses pendidikan pada satuan pendidikan. Pendidik merupakan tenaga profesional yang bertugas merencanakan dan melaksanakan proses pembelajaran, menilai hasil pembelajaran, melakukan pembimbingan dan pelatihan, serta melakukan penelitian dan pengabdian kepada masyarakat, terutama bagi pendidik pada perguruan tinggi. Sesuai dengan fungsi dan tujuan Pendidikan Nasional yaitu menciptakan sumber daya manusia yang berkualitas, diperlukan pendidikan yang dapat mengembangkan kepribadian, kecerdasan, keterampilan serta menambah wawasan menjadi lebih luas dan dapat mengembangkan potensi diri pribadi.

Tugas guru erat kaitannya dengan peningkatan sumber daya manusia melalui sektor pendidikan, oleh karena itu perlu upaya-upaya untuk meningkatkan mutu guru untuk menjadi tenaga profesional. Untuk menjadikan guru sebagai tenaga profesional maka perlu diadakan pembinaan secara terus menerus dan berkesinambungan, dan menjadikan guru sebagai tenaga kerja perlu diperhatikan, dihargai dan diakui keprofesionalannya. Untuk membuat mereka menjadi professional tidak semata-mata hanya meningkatkan kompetensinya baik melalui pemberian penataran, pelatihan maupun memperoleh kesempatan untuk belajar lagi namun perlu juga memperhatikan guru dari segi yang lain seperti peningkatan disiplin, pemberian motivasi, pemberian bimbingan melalui supervisi, pemberian insentif, gaji yang layak dengan keprofesionalnya sehingga memungkinkan guru menjadi puas dalam bekerja sebagai pendidik.

Salah satu faktor yang menjadi tolak ukur keberhasilan sekolah adalah kinerja guru dalam mengajar. Kinerja guru atau prestasi kerja adalah suatu hasil kerja yang dicapai seseorang dalam melaksanakan tugas-tugas yang pengajaran, kerjasama dengan semua warga sekolah, kepemimpinan yang menjadi panutan siswa, kepribadian yang baik, jujur dan objektif dalam membimbing siswa, serta tanggung jawab terhadap 
Efekțivitas Supervisi Kepala Sekolah Dalam Peningkatan Mutu Lulusan (Studi Kasus Di Sekolah Menengah Kejuruan Pelita IV Jakarta Barat), 2018

tugasnya. Kinerja dikatakan baik dan memuaskan apabila tujuan yang dicapai sesuai dengan standar yang telah ditetapkan. Oleh karena itu tugas kepala sekolah selaku manager adalah melakukan penilaian terhadap kinerja mengajar guru. Penilaian ini penting untuk dilakukan mengingat fungsinya sebagai alat motivasi bagi pimpinan kepada guru maupun bagi guru itu sendiri. Akan tetapi, hasil observasi empirik di lapangan mengindikasikan, bahwa sebagian besar lulusan sekolah menengah kejuruan (SMK) kurang mampu menyesuaikan diri dengan perubahan maupun perkembangan ilmu pengetahuan dan teknologi, sulit untuk bisa dilatih kembali, dan kurang bisa mengembangkan diri.

Temuan tersebut tampaknya mengindika si bahwa pembelajaran di SMK belum banyak menyentuh atau mengembangkan kemampuan adaptasi peserta didik. Studi itu juga memperoleh gambaran bahwa sebagian lulusan dibebankan kepadanya yang didasarkan atas kecakapan, pengalaman, dan kesungguhan serta waktu (Hasibuan, 2007: 94). Kinerja mengajar guru akan baik jika guru telah melakukan unsur- unsur yang terdiri dari kesetiaan dan komitmen yang tinggi pada tugas mengajar, menguasai dan mengembangkan bahan pelajaran, kedisiplinan dalam mengajar dan tugas lainnya, kreativitas dalam pelaksanaan SMK tidak bisa masuk di lapangan kerja, karena kompetensi yang mereka miliki belum sesuai dengan tuntutan dunia kerja, fenomena yang terjadi pada lulusan pendidikan kejuruan adalah :

1. Pengetahuan dan ketrampilan dasar pada bid ang tertentu masih lemah, sehingga kepercayaan diri dalam memasuki lapangan kerja kurang atau bahkan belum siap sama sekali.

2. Tidak mempunyai orientasi masa depan atau visi ke depan yang tidak jelas.

3. Industri tidak percaya pada kemampuan pen getahuan dan ketrampilan lulusan pendidika $\mathrm{n}$ kejuruan, yang seharusnya mutu lulusan $\mathrm{p}$ endidikan kejuruan juga merupakan tanggung jawab moral industri.

Berdasarkan hal tersebut, disadari bahwa kepala sekolah melalui supervisi akademiknya dan guru dengan pembelajarannya yang bermutu, akan sangat menentukan terhadap terciptanya sekolah yang memiliki mutu lulusan yang baik, yaitu mutu siswa yang mempunyai kemampuan dan keterampilan sesuai dengan tuntutan dan keinginan masyarakat dalam angka menjawab tantangan moral, mental, dan perkembangan ilmu pengetahuan serta teknologi.

\section{KAJIAN PUSTAKA}

\section{Pelaksanaan Supervisi oleh Kepala Sekolah}

kontribusi supervisi sangat diperlukan dalam rangka mengembangkan situasi belajar mengajar yang lebih baik melalui pembinaan dan peningkatan profesi mengajar. Supervisi akademis terhadap guru mampu membangun talenta positif terhadap kinerja guru dalam pendidikan khususnya Kegiatan Belajar Mengajar (KBM) . Oleh sebab itu, dalam konteks makro, supervisi merupakan suatu kegiatan pelayanan terhadap guru untuk memutakhirkan kemampuan profesionalisme guru. Karena melalui supervisi guru akan mendapatkan pembinaan konstruktif tentang berbagai inovasi serta strategi pembelajaran yang optimal. 


\section{Profesionalisme Guru}

Menurut Martinis Yamin profesi mempunyai pengertian seseorang yang menekuni pekerjaan berdasarkan keahlian, kemampuan, teknik, dan prosedur berlandaskan intelektualitas (Kunandar, 2006: 3). Jasin Muhammad yang dikutip oleh Yunus Namsa, beliau menjelaskan bahwa profesi adalah suatu lapangan pekerjaan yang dalam melakukan tugasnya memerlukan teknik dan prosedur ilmiah, memiliki dedikasi serta cara menyikapi lapangan pekerjaan yng berorientasi pada pelayanan yang ahli. Pengertian profesi ini tersirat makna bahwa di dalam suatu pekerjaan profesional diperlukan teknik serta prosedur yang bertumpu pada landasan intelektual yang mengacu pada pelayanan yang ahli (Namsa, 2005: 29).

Guru sebagai profesi berarti guru sebagai pekerjaan yang mensyaratkan kompetensi (keahlian dan kewenangan) dalam pendidikan dan pembelajaran agar dapat melaksanakan pekerjaan tersebut secara efektif dan efisien serta berhasil guna (Kunandar, 2007: 46).

Guru yang profesional adalah orang yang terdidik dan terlatih dengan baik, serta memiliki pengalaman yang kaya di bidangnya (Kunandar, 2007: 46-47) Sedangkan Oemar Hamalik mengemukakan bahwa guru profesional merupakan orang yang telah menempuh program pendidikan guru dan memiliki tingkat master serta telah mendapat ijazah negara dan telah berpengalaman dalam mengajar pada kelas-kelas besar (Hamalik, 2006: 27).

Kompetensi profesional adalah keterampilan penyesuaian bahan mata pelajaran pembelajaran secara luas dan mendalam yang memungkinkan membimbing siswa memenuhi standar kompetensi yang ditetapkan dalam Standar Nasional Pendidikan; Kompetensi social yaitu keterampilan guru sebagai bagian dari masyarakat untuk berkomunikasi dan bergaul secara efektif dengan siswa, tenaga kependidikan, orangtua/wali siswa, dan masyarakat sekitar (PP No.19/2005). Dari beberapa uraian di atas, dapat disimpulkan bahwa guru yang profesional adalah guru yang terdidik dan terlatih dengan baik, menekuni pekerjaannya, mempunyai karakter baik serta dapat menjadi teladan bagi peserta didik.

\section{Mutu Lulusan Sekolah Menengah Kejuruan}

Hakekat mutu pendidikan, menurut Tampubolon (dalam Sambasalim, 2009) mutu adalah paduan sifat-sifat produk yang menunjukkan kemampuannya dalam memenuhi kebutuhan pelanggan, baik kebutuhan yang dinyatakan atau kebutuhan yang tersirat, masa kini dan masa depan. Sedangkan menurut Crosby (dalam Sambasalim, 2009) mutu mengandung makna kesesuaian dengan kebutuhan. Berdasarkan pendapat di atas dapat didefinisikan bahwa mutu adalah perpaduan sifatsifat barang atau jasa, yang menunjukkan kemampuannya dalam memenuhi kebutuhan dan kepuasan bahkan melebihi harapan pelanggan, baik yang tersurat maupun yang tersirat.

Output (keluaran) pendidikan merupakan kinerja sekolah. Kinerja sekolah adalah prestasi sekolah yang dihasilkan dari proses/perilaku sekolah. Kinerja sekolah dapat diukur dari kualitasnya, efektivitasnya, produktivitasnya, efesiensinya, inovasinya, kualitas kehidupan kerjanya dan moral kerjanya. Khusus yang berkaitan dengan mutu output (keluaran) sekolah, dapat dijelaskan bahwa output sekolah dikatakan 
Efekțivitas Supervisi Kepala Sekolah Dalam Peningkatan Mutu Lulusan (Studi Kasus Di

Sekolah Menengah Kejuruan Pelita IV Jakarta Barat), 2018

berkualitas/bermutu tinggi jika prestasi sekolah Sedangkan dalam konteks pendidikan pengertian mutu mencakup input (masukan), proses, dan output (keluaran) pendidikan. Input (masukan) pendidikan adalah segala sesuatu yang harus tersedia karena dibutuhkan untuk berlangsungnya suatu proses. Input perangkat lunak meliputi struktur organisasi sekolah, peraturan perundang-undangan, deskripsi tugas, rencana, program. Input (masukan) merupakan harapan-harapan berupa visi, misi, tujuan, dan sasaran-sasaran yang ingin dicapai oleh sekolah (Sambasalim,2009). Output (keluaran) pendidikan merupakan kinerja sekolah. Kinerja sekolah adalah prestasi sekolah yang dihasilkan dari proses/perilaku sekolah. Kinerja sekolah dapat diukur dari kualitasnya, efektivitasnya, produktivitasnya, efesiensinya, inovasinya, kualitas kehidupan kerjanya dan moral kerjanya. Khusus yang berkaitan dengan mutu output (keluaran) sekolah, dapat dijelaskan bahwa output sekolah dikatakan berkualitas/bermutu tinggi jika prestasi sekolah, khususnya hasil akhir atau nilai Ujian Nasional siswa, khususnya hasil akhir atau nilai Ujian Nasional siswa, Berdasarkan pendapat di atas, perubahan paradigma harus dilakukan secara bersama-sama antara pimpinan dan karyawan sehingga mereka mempunyai langkah dan strategi yang sama yaitu menciptakan mutu dilingkungan kerja khususnya lingkungan kerja pendidikan yaitu dengan meluluskan siswa yang berkualitas. Pimpinan dan karyawan harus menjadi satu tim yang utuh (teamwork) yang saling membutuhkan dan saling mengisi kekurangan yang ada sehingga target (goals) akan tercipta dengan baik.

\section{METODOLOGI PENELITIAN}

Penelitian ini menggunakan pendekatan kualitatif yang bersifat fleksibel dan terbuka untuk perubahan dan penyesusaian pada saat penelitian sehingga tidak ada batasan bagi peneliti untuk menemukan hal-hal baru yang terkait dengan topik penelitian.

Penelitian kualitatif juga menempatkan peneliti sebagai orang yang belajar dari masyarakat sehingga peneliti ini cenderung sesuai dengan kenyataan yang ada di lapangan. Data yang diperoleh dari hasil observasi di lapangan dan wawancara dengan narasumber dilakukan secara mendalam (in-dept-interview).

Penelitian ini dilaksanakan di tahun ajaran 2016/2017. Penelitian ini dilakukan secara bertahap, secara garis besar dibagi menjadi 3 tahap, yaitu:

1. Tahap persiapan, adalah tahap yang dilakukan oleh peneliti untuk mendukung kegiatan penelitian. Dalam tahap ini yang dilakukan oleh peneliti meliputi permohonan ijin observasi sekolah, pengajuan judul tesis, penyusunan proposal dan konsultasi dengan pembimbing. Tahap ini dilaksanakan pada bulan Maret 2016.

2. .Tahap penelitian, adalah tahap dari peneliti memulai kegiatan penelitian. Tahap ini meliputi semua kegiatan yang berlangsung di lapangan, yaitu pelaksanaan observasi dan pengambilan data. Tahap ini dilaksanakan pada bulan Juli sampai dengan September 2016.

3. Tahap penyelesaian, tahap ini meliputi analisis data dan penyusunan laporan. Tahap ini dilaksanakan pada bulan September 2017.

Pengumpulan data dilakukan pada natural setting ( kondisi alami). Teknik pengumpulan data dilakukan melalui pengamatan (observasi), wawancara, 
dokumentasi dan trianggulasi.

Model analisis yang digunakan dalam penelitian ini adalah analisis interaktif yaitu model analitis yang menyatu dengan proses pengumpulan data dalam suatu siklus. Menurut Miles dan Huberman (1994:16) "Analisis mengalir dalam tiga alur kegiatan yang terjadi secara bersama-sama yaitu: reduksi data, penyajian data, dan penarikan kesimpulan atau verifikasi." Jadi, antara reduksi data, penyajian data, dan penarikan kesimpulan dilakukan sebelum, selama dan sesudah pengumpulan data dalam bentuk yang sejajar untuk membangun suatu analisis yang tangguh.

Reduksi data meliputi proses penyeleksian, pemfokusan, dan penyederhanaan dari data lapangan (hasil wawancara, hasil observasi, hasil dokumentasi, dll) yang berlangsung sepanjang kegiatan pelaksanaan penelitian dengan menggunakan salah satu data yang dianggap paling relevan dari beberapa sumber data yang telah diperoleh. Penyajian data meliputi penyusunan informasi secara sistematik dari hasil reduksi data yang disajikan dalam bentuk table, diagram, maupun grafik. Penarikan kesimpulan atau verifikasi merupakan upaya pencarian makna data, mencatat keteraturan dan penggolongan data.

Penentuan kriteria tersebut mengacu pada aturan pengelompokan kategori yangdikemukakan oleh Saifuddin Azwar dan telah diubah dan sesuai dengan penelitian analisis kontribusi supervisi kepala sekolah dan profesionalisme guru terhadap mutu lulusan Sekolah Menengah Kejuruan Pelita IV Jakarta Barat untuk peranan supervisi kepala sekolah yaitu aspek perencanaan, pelaksanaan, evaluasi,pengawasan dan untuk profesionalisme kerja guru, efektivitas aspek pedagogik, kepribadian, social dan professional.

\section{HASIL PENELITIAN DAN PEMBAHASAN}

Tugas pokok kepala sekolah adalah merencanakan, melaksanakan, mengevaluasi dan mengawasi pembelajaran di sekolah. Dengan kata lain tugas kepala sekolah adalah dengan memberikan arahan dan pembinaan dalam proses pembelajaran di sekolah. Kepala sekolah sebagai supervisor diharapkan mengetahui dan memberi solusi terhadap permaslahan yang terjadi.

Supervisi yang dilakukan oleh kepala sekolah berupa dorongan, bimbingan dan kesempatan dari pertumbuhan keahlian dan kecakapan guru-guru seperti bimbingan dalam usaha pelaksanaan pembaharuan dalam pendidikan dan pengajaran, pemilihan alat-alat pelajaran dan metode mengajar yang lebih baik, perencanaan, pelaksanaan, evaluasi dan pengawasan. Dalam tiap-tiap aspek tersebut didalamnya terdapat indikator-indikator ynag mengidentifikasikan dan merujuk ke tiap aspek tersebut.

Kesempurnaan jalannya pembelajaran masing-masing sekolah tidak dapat dipisahkan dari peran sekolah, yakni kepala sekolah. Sebagai pimpinan, seorang kepala sekolah tidak dapat lepas dari kegiatan-kegiatan manajerial, salah satunya adalah supervisi atau pengawasan. Dengan menjalankan peran supervisi inilah, maka seorang kepala sekolah dapat dikatakan sebagai supervisor dalam pendidikan.

Berdasarkan dari kajian teori dan berbagai sumber teori peneliti telah membuat pedoman observasi yang digunakan sebagai acuan dalam melakukan observasi secara langsung bagaimana supervisi tersebut dilakukan dan bagaimana cara para guru mengajar, menyampaikan materi ajar kepada siswa didiknya. Pasca observasi peneliti 
Efekțivitas Supervisi Kepala Sekolah Dalam Peningkatan Mutu Lulusan (Studi Kasus Di

Sekolah Menengah Kejuruan Pelita IV Jakarta Barat), 2018

mendapatkan data-data dalam pelaksanaan supervisi yang terjadi di SMK Pelita IV Jakarta Barat sebagai berikut:

1) Aspek Perencanaan

Aspek supervisi kepala sekolah yang pertaman yaitu tahap perencanaan. Dari hasil observasi menunjukkan peran kepala sekolah baik, hal ini didukung dengan beberapa indikator yaitu informasi kepada jajaran guru tentang akan diadakannya supervisi, pemrograman supervisi secara dilakukan kepada beberapa guruyang direncanakan akan disupervisi.

2) Aspek Pelaksanaan

Aspek supervisi yang kedua yaitu pelaksanaan, dari hasil observasi yang dilakukan, menunjukkan bahwa teknis pelaksanaan supervisi yang dilakukan oleh kepala sekolah sangat baik. Kepala sekolah selaku supervisor sudah menunjukkan indikator-indikator sebagai berikut: memberikan salam kepada guru yang mengajar, mencari tempat duduk yang tidak mencolok, tidak menegur kesalahan guru di dalam kelas, mencatat setiap kegiatan, mempersiapkan isian berupa check list, memerhatikan kondisi kelas baik guru maupun siswanya.

Pelaksanaan supervisi kepada guru pengajar dilakukan oleh supervisor dengan terlebih dahulu memberikan salam dan pengantar kepada siswa. Hal ini dimaksudkan agar siswa tidak grogi atau tegang, supervisor menjaga agar para siswa bersikap biasa dan tidak terganggu atas adanya guru lain (supervisor) di dalam kelasnya. Semua berkas telah dipersiapkan oleh supervisor dan guru pengajar juga telah menyiapkan temat duduk yaitu yang paling belakang. Supervisor juga tetap tenang dan berusaha menyesuaikan terhadap kondisi kelas.

Supervisor secara fokus mengamati cara mengajar guru juga kondisi kelas yang terjadi. Supervisor juga mencatat beberapa poin yang terjadi di dalam kelas baik tentang perilaku guru, perangkat pembelajaran, ataupun kondisi siswa selain itu juga mengisi isian dalam berkas yang telah dibawanya langsung di dalam kelas. Sesaat sebelum pelajaran diakhiri supervisor kembali memberi salam kepada siswa dan guru pengajar untuk mohon ijin undur diri.

Pelaksanaan supervisi tidak mengganggu kelas, semua telah dipersiapkan untuk mendukung kelancaran supervisi. Indikator-indikator yang mengindikasikan aspek perencanaan tidak semua dilaksanakan. Penggunaaan alat elektronik tidak dilakukan sebagai media dokumentasi. Namun secara garis besar dalam kegiatan tersebut sudah baik karena siswa maupun guru mampu melaksanakan pembelajaran secara wajar dan tidak merasa terbebani karena ada guru lain yang masuk ke dalam kelas.

Pelaksanaan supervisi di SMK Pelita IV Jakarta Barat dalam satu semester dilaksanakan minimal satu kali oleh kepala sekolah atau yang mewakili.

3) Aspek Evaluasi

Asek supervisi kepala sekolah yang ketiga adalah evaluasi. Dari hasil observasi yang dilakukan menunjukkan bahwa teknis dalam pelaksanaan supervisi dapat dikatakan baik sekali. Beberapa indikator yang termasuk dalam hal ini meliputi supervisor membicarakan hasil supervisi kepada guru 
yang disupervisi, mempersiapkan evaluasi, memilih / merencanakan tempat percakapan, memilih / merencanakan waktu percakapan, percakapan tidak keluar dari data observasi, guru diberi kesempatan dialog dan mengeluarkan pendapat, menjelaskan bahwa kelemahan guru hendaknya menjadi motivasi guru dalam memperbaiki kelemahan. Saran untuk perbaikan diberikan yang mudah dan praktis. Hasil pembicaraan didokumentasikan menurut masingmasing guru yang telah diobservasi.

Evaluasi dari supervisor dilaukan tidak langsung ditempat melainkan membuat kesepakatan kembali dengan guru untuk waktu dan tempatnya. Hal yang disoroti utamanya pada materi yang disampaikan dan pemanfaatan media yang telah disiapkan sekolah. Beberapa guru ada yang masih menyampaikan materi secara konvensional dan diarahkan oleh supervisor ke pemanfaatan media. Menurut para guru sendiri fasilitas yang diberikan sekolah sudah cukup lumayan dan menunjang untuk penyampaian materi. Namun, hal tersebut kurang begitu dimanfaatkan oleh beberapa guru khususnya guru yang sudah senior.

Arahan dari supervisor kepada guru juga mengarah pada relevansi materi dan pemanfaatan media.

4) Aspek Pengawasan

Aspek supervisi yang keempat adalah pengawasan. Dari hasil observasi yang dilakukan menunjukkan bahwa teknis dalam pengawasan dapat dikatakan baik, dengan indikator-indikator diantaranya kepala sekolah mempunya dokumen data guru yang telah disupervisi, isi dokumen sesuai dan dimulai dari tanggal, tujuan, data yang diperoleh, catatan diskusi, pemecahan masalah dan saran- saran. Kepala sekolah laporan dan mempelajari laporan guru pengajar, kepala sekolah memberikan saran / umpan balik saat guru yang telah disupervisi mengalami kesulitan, kepala sekolah memberikan saransaran kepada guru pengajar baik dalam kondisi formal maupun non formal, kepala sekolah sering kali berkeliling di lingkungan sekolah untuk memantu / memastikan kegiatan belajar mengajar di sekolahnya, kepala sekolah meminta laporan perkembangan pembelajaran yang dilakukan guru setelah adanya evaluasi dari supervisi.

Tipe supervisi yang dilakukan oleh kepala sekolah mengarah ke demokratis dalam arti tetap mengakomodir dari pendapat para guru. Berdasarkan pembahasan dan analisis apek- aspek secara keseluruhan dan ditinjau dari pedoman kriteria prosentase dalam analisis untuk Efektivitas Supervisi Kepala Sekolah di SMK Pelita IV Jakarta Barat, sudah baik, meliputi perencanaan, pelaksanaan, evaluasi dan pengawasan. Masih ada beberapa indikator yang belum sepenuhnya optimal. Perlengkapan, sarana prasarana dan media yang bisa dibilang sudah cukup memadai dan mendukung di SMK Pelita IV Jakarta Barat tersebut kurang begitu dimaksimalkan oleh kepala sekolah, salah satu contohnya adalah pemanfaatan media dokumentasi (alat perekam, kamera dan tape recorder, dll) dalam pelaksanaan supervisi.

Seharusnya hal tersebut bisa untuk diminimalkan lagi karena pada dasarnya segala indikator di dalamnya bergantung dari dalam supervisor / kepala 
Efekttivitas Supervisi Kepala Sekolah Dalam Peningkatan Mutu Lulusan (Studi Kasus Di

Sekolah Menengah Kejuruan Pelita IV Jakarta Barat), 2018

sekolah sendiri.

\section{KESIMPULAN, IMPLIKASI DAN SARAN \\ Kesimpulan}

Berdasarkan penelitian tentang Efektivitas Supervisi Kepala Sekolah dalam Peningkatan Mutu Lulusan (Studi Kasus di Sekolah Menengah Kejuruan Pelita IV Jakarta Barat) dapat disimpulkan bahwa: Kepala sekolah SMK Pelita IV Jakarta Barat melaksanakan supervisi secara terprogram/terjadwal (jadwal supervisi terlampir) Biasanya kepala sekolah membeitahukan terlebih dulu kepada guru yang akan disupervisi. Tujuan kepala sekolah melaksanakan supervisi adalah untuk meningkatkan kinerja guru. Tanggapan para guru terhadap supervisi yang dilakukan kepala sekolah adalah para guru merasa senang karena termotivasi untuk meningkatkan pembelajaran dan lebih giat dan bersemangat dalam melaksanakan tugasnya Teknik supervisi yang biasa digunakan oleh kepala sekolah adalah kunjungan kelas, dan mengontrol keadaan kelas dengan cara berkeliling dari kelas ke kelas. Umpan balik/tindak lanjut dari kepala sekolah .juga dilakukan dengan memanggil guru yang bersangkutan sejumlah guru di SMK Pelita IV yaitu 24 orang untuk memberikan masukan. Hambatan yang dihadapi kepala sekolah dalam melaksanakan supervisi adalah tidak sesuainya antara jadwal yang sudah dibuat dengan pelaksanaannya.

Kontribusi profesionalisme guru terhadap mutu lulusan sudah dapat dikatakan baik, hal ini terlihat dari jumlah keterserapan lulusan SMK Pelita IV di perguruan tinggi dan di beberapa perusahaan. Hal ini terliat dari catatan dokumentasi sekolah tentang penelusuran lulusan siswa. (data terlampir) Kontribusi supervisi kepala sekolah terhadap mutu lulusan juga sudah baik, karena dengan adanya supervisi dari kepala sekolah ke guru, memacu guru untuk mengajar dengan semangat, giat, lebih kreatif dan ini berpengaruh terhadap prestasi siswa hal ini terlihat dari piala yang diperoleh , hasil NEM dan UAN yang bagus. (data terlampir). Pelaksanaan supervisi kepala sekolah sangat efektif dalam meningkatkan profesionalisme guru karena supervisi dilakukan secara kontinu, sehingga guru pun mendapatkan bimbingan/binaan/masukan dari kepala sekolah secara kontinu pula. Dengan demikian, kinerja guru terus meningkat hal ini berdamat pada mutu lulusan.

\section{Implikasi}

Melalui temuan penelitian ini, peneliti akan memaparkan dua implikasi, yaitu implikasi praktis dan implikasi teori. Implikasi Praktis Penelitian ini mempunyai dua implikasi praktis, yaitu bagi kepala sekolah dan guru di SMK Pelita IV Jakarta Barat. Kepala SMK Pelita IV Jakarta Barat. Tujuan diadakannya supervisi oleh kepala sekolah adalah untuk meningkatkan kinerja guru. Oleh sebab itu, kepala sekolah dengan tugasnya sebagai supervisor dapat membimbing, membina para guru agar kinerja para guru lebih baik. Pada dasarnya, supervisi yang dilakukan oleh kepala sekolah sudah berjalan dengan baik. Kepala sekolah memberitahukan terlebih dulu kepada para guru yang akan disupervisi.Akan tetapi, masih ada hambatan, yaitu kadang pelaksanaannya tidak sesuai dengan jadwal.

a. Guru - guru SMK Pelita IV Jakarta Jakarta Barat.

Hasil penelitian ini digunakan sebagai masukan bagi para guru agar para 
guru selalu siap kapan saja untuk disupervisi oleh kepala sekolah. Para guru dapat menerima masukan/kritikan, dari kepala sekolah dengan lapang dada, dengan perasaan senang, mengingat bahwa supervisi memang sebagai sarana pembinaan dari kepala sekolah kepada para guru. Di samping itu, para guru juga dapat menggunakan sarana dan prasarana yang ada dengan baik. Dengan demikian, kinerja guru semakin meningkat, dan akhirnya mutu lulusan meningkat pula.

\section{Implikasi Teoritis}

Secara teoritis, dalam penelitian ini ditemukan masukan berharga baik bagi kepala sekolah maupun guru , bahkan bagi pemerintah., khususnya dinas pendidikan. Kepala sekolah dapat menjalankan tugasnya sebagai supervisor dengan profesional, guru dapat melaksanakan tugasnya dalam mengajar dan mendidik anak-anak dengan berkompeten, dan dinas pendidikan dapat memberikan bantuan sarana dan prasarana yang dibutuhkan oleh sekolah dengan memadai. Dengan demikian, tujuan pendidikan untuk mencerdaskan kehidupan bangsa dapat tercapai, karena dengan pendidikan yang berkualitas akan dapat menciptakan sumber daya manusia yang berkualitas pula.

\section{Saran}

1) Dalam kaitannya dengan tugas kepala sekolah sebagai supervisor, peneliti menyarankan agar kepala sekolah juga dapat menjalankan tugasnya sebagai manajer - mengarahkan, memimpin para guru - dan sebagai motivator, yaitu memberikan dukungan dalam proses pembelajaran, melalui kegiatan umpan balik setelah mengadakan supervisi. Di samping itu, kepala sekolah juga harus dapat membuat jadwal supervisi dengan lebih arif bijaksana, sehingga hambatan dalam pelaksanaan supervisi dapat diminimalkan.

2) Dalam penggunaan sarana dan prasarana, peneliti menyarankan agar guru lebih dapat mengefektifkan penggunaan sarana dan prasarana sehingga pembelajaran lebih menyenangkan.

3) Mengingat, bahwa dampak supervisi kepala sekolah terhadap profesionalisme guru sangat berpengaruh terhadap mutu lulusan, peneliti menyarankan agar pelaksanaan supervisi secara kontinu terus diadakan, dan pihak sekolah terus mengontrol atau mengadakan penelusuran lulusan sehingga memacu angkatan yang dibawahnya untuk berprestasi.

\section{DAFTAR PUSTAKA}

Abdullah. Boedi. 2016. Supervisi Pendidikan.Bandung: Pustaka Setia. Ahmad.2010.Pedoman Pembinaan Profesional Guru Sekolah Dasar. Jakarta: Depdiknas.

Anonim. 2012. Uji Kompetensi Guru. http://www.ujikompetensiguru.com/201 2/03/pengumuman-uji-kompetensi-awalguru.html, diakses 18 Januari 2015

Afifudin. 2007. Kinerja Guru Madrasah Aliyah. Studi tentang Pengaruh Kepemimpinan Kepala Madrasah, supervise Akademik, dan Budaya Organisasi terhadap Kinerja Guru Madrasah Aliyah Negeri di Jawa Barat. Disertasi bandung: 
Efektivitas Supervisi Kepala Sekolah Dalam Peningkatan Mutu Lulusan (Studi Kasus Di Sekolah Menengah Kejuruan Pelita IV Jakarta Barat), 2018

Universitas Islam Negeri Bandung. Tidak dipublikasikan.

Arikunto, S. 2005. Prosedur Penelitian Suatu Pendekatan Praktek. Jakarta: Rineka Cipta.

Atmodiwirio, S. 2000. Manajemen Pendidikan Indonesia. Jakarta: Ardadizya Jaya. Emzir. 2015. Metodologi Penelitian Pendidikan Kuantitatif dan Kualitatif. Depok: PT Raja Grafindo Persada.

Eneng Muslihah. Kontribusi Supervisi Kepala sekolah Model Pengembangan terhadap Profesionalisme Guru Sekolah Menengah Atas Negeri Provinsi Banten.

Hadis, A. 2005. Kontribusi Supervisi Kepala Sekolah, Profesionalisme dan Kinerja Guru terhadap Mutu Proses dan Hasil Belajar Siswa di SMAN Kota Bandung, Jurnal Mimbar Pendidikan. No. 2/XXIV/2005. H. 40-46.

Junarsih. 2012. Pengembangan Sistem Profesionalisme Guru. Bandung: Andira Lubis, P. 2007. Pengaruh Profesionalisme Guru dan Iklim Kerja terhadap Efektivitas kerja Guru SMA 90 jakarta Selatan. Tesis. Jakarta: Program Pascasarjana Magister Manajemen Pendidikan Universitas Budiluhur. Tidak Diterbitkan.

Moleong, Lexy J. 2013. Metodologi enelitan Kualitatif. Bandung: PT Remaja Rosda Karya.

Mulyasa, E. 2005. Menjadi Guru Profesional Menciptakan Pembelajaran Kreatif. Bandung: Remaja.

Najib, Mohammad. 2015. Metodologi Penelitian Manajemen Pendidikan sebuah Pengantar. Bandung: Pustaka Setia

Nurdin, S dan Usman, B. 2002. Guru Profesional dan Implementasi Kurikulum. Jakarta: Ciputat Pers.

Siagian. Harbangan.1993. Manajemen Suatu Pengantar. Semarang: Satya Wacana. Thoha, Miftah. 2013. Kepemimpinan dalam Manajemen. Jakarta: PT Rajagrafindo Persada.

UPI Tim Dosen Administrasi Pendidikan . 2009. Manajemen Pendidikan. Bandung: Alfabeta.

Uwes, H. Sanusi dan H.A. Rusdiana. Sistem Pemikiran Alternatif Memecahkan Masalah Pendidikan. 
